\title{
ALDH1A1 wt Allele
}

National Cancer Institute

\section{Source}

National Cancer Institute. ALDH1A1 wt Allele. NCI Thesaurus. Code C116057.

Human ALDH1A1 wild-type allele is located in the vicinity of 9q21.13 and is approximately $180 \mathrm{~kb}$ in length. This allele, which encodes retinal dehydrogenase 1 protein, plays a role in retinoic acid metabolism. 